\title{
PRODUCTIVITY OF MUSTACHIOED PEA VARIETIES DEPENDING ON THE NUTRITION BACKGROUND UNDER THE CONDITIONS OF THE EASTERN FOREST-STEPPE OF UKRAINE
}

Popov S.I., Hlubokyi O.M.

Plant Production Institute nd. a. V.Ya. Yuriev of NAAS, Ukraine

The peculiarities of forming the cropping capacity and grain quality of modern pea varieties depending on the system of basic fertilization in crop rotation have been established. At unstable weather conditions, the maximum productivity was provided by Tsarevych, Haiduk and Oplot varieties against the background of manure aftereffect $+\mathrm{N}_{30} \mathrm{P}_{30} \mathrm{~K}_{30}$ in the main application. The difference in grain quality between varieties and nutrition backgrounds has been revealed. The highest protein content of grain was provided by the least productive varieties Corvet and Malakhit. The possibility of simultaneous growth of cropping capacity and protein content in grain of Haiduk variety has been established. The most significant gross protein harvest was obtained on organomineral background of fertilization in Haiduk, Oplot and Tsarevych varieties. The increase in gross protein harvest per hectare in most varieties depended more on the level of their cropping capacity than on the protein content in the grain.

Key words: peas, variety, nutrition background, productivity, grain quality, protein harvest.

Introduction. Significant food, fodder and agrotechnical significance of field pea (Pisum sativum L.) is due to the high protein content in the grain, its balance in amino acid composition, as well as the ability of plants to symbiotic fixation of nitrogen [1,2]. It is one of the best precursors of grain crops as it improves soils fertility, especially with insufficient application of mineral and organic fertilizers. Pea grain production in Ukraine has been growing in recent years, but there is no stability over the years. With the emergence of the mustachioed morphotype varieties, it became possible to increase the sowing areas of pea. But at the same time, the requirements for the variety have increased, which must have a high adaptive ability to restore to the optimal level of metabolic processes aftereffects of the stress factor, which is especially important under conditions of climate changes. It is necessary to introduce in production new drought-resistant pea varieties with limited stem growth and compact placement of beans, which have increased resistance to lodging and seed shedding, as well as more friendly ripening $[2,3,4]$.

Analysis of literature data and problem statement. Mustachioed pea varieties which have been created at Plant Production Institute nd. a. V.Ya. Yuriev of NAAS over the past decade, have high resistance to lodging and drought resistance, uniform ripening, reduced degree of beans cracking, and most importantly - are suitable for harvesting by direct combining with a potential grain cropping capacity at the level of 4.6-6.0 t/ha [5]. Due to well-developed and firmly linked tendrils, in crops conditions are created for sufficient aeration and illumination of the lower storey of plants. But the high potential of their cropping capacity can be maximally realized when growing using technologies that involve the complex application of intensification factors and the creation of optimal conditions for plant growth and development at each stage of organogenesis $[6,7,8,9]$.

The biological peculiarity of peas is a long period of generative development. Unfavorable weather conditions that occur during this period for pea varieties that differ in the accumulation of plastic substances are the main reason for the decrease in seed yield. One of the properties of varieties is also their different reaction and the return of the grain yield to fertilizer application, which must be taken into account in order to more fully realize their productivity. It should be noted that earlier, when growing leaf varieties, fertilizers application directly under pea on the chernozem lands of Ukraine was considered impractical due to excessive plant development, inhibition of

(C) S.I. Popov, O.M. Hlubokyi. 2021.

ISSN 1026-9959. Селекція і насінництво. 2021. Випуск 119 
ripening and thereby a decrease in grain yield. As a result, fertilizers were recommended to be applied under the predecessors of pea - sugar beet and corn [10].

During the period of germination and flowering, pea assimilates $60-100 \%$ of the needed potassium and $30-65 \%$ of phosphorus. Lack of phosphorus in the soil leads to disruption of the activity of nodule bacteria, negatively affects the tying of beans and grain filling, and slows down the ripening. Phosphorus-potash fertilizers applied for autumn ploughing significantly increase grain yield, accelerate the ripening and resistance of plants to diseases [11]. Compared to the application for pre-sowing cultivation, the main application increases the efficiency of fertilizers by $10-30 \%$, and in dry years - by $40-50 \%$ [12].

Under conditions of production, the effectiveness of agrotechnical methods of pea growing is largely influenced by unfavorable agrometeorological conditions during the growing season, as evidenced by numerous studies [8, 13]. It should be taken into account that pea has an underdeveloped root system, is very demanding of light, moisture and soil nutrition [14]. For the formation of 1 centner of grain, pea takes a significant amount of nutrients from the soil, namely: nitrogen - 4.5-6.0 kg, phosphorus - 1.7-2.0 kg, potassium - 3.5-4.0 kg, calcium - 2.5-3.0 kg, magnesium $-0.8-1.3 \mathrm{~kg}$, as well as microelements: molybdenum, boron and others [15]. The most effective agricultural method for increasing the cropping capacity and quality of pea grain is the application of fertilizers, which significantly level the degree of crop shortage, especially under unfavorable weather conditions [8].

Based on this, it is important to study the impact of fertilizer, taking into account specific soil and climatic conditions. Due to the biological ability of plants to assimilate atmospheric nitrogen and phosphorus from hard-to-dissolve forms of fertilizers and soil, the pea fertilization system has its own peculiarities. According to H. M. Hospodarenko's calculations [14], the rate of nitrogen fertilizers for pea, taking into account the share obtained due to nitrogen fixation, should be $60-75 \mathrm{~kg} / \mathrm{ha}$. In addition, a lack of nitrogen nutrition before the beans formation reduces the resistance of plants to drought. Under conditions of unstable moisture on podzolized chernozem, pea reacted well to increased fertilizer doses in the aftereffect of 20 tons of manure $+{ }^{N_{90}} \mathrm{P}_{60} \mathrm{~K}_{80}$ and 30 tons of manure $+\mathrm{N}_{110} \mathrm{P}_{70} \mathrm{~K}_{100}$ with an increase in cropping capacity by $0.9 \mathrm{t} / \mathrm{ha}$ [16]. According to Burkina S. I. [et al.], the application of mineral fertilizers at a dose of $\mathrm{N}_{30} \mathrm{P}_{30} \mathrm{~K}_{30}$ against the background of the third year of manure aftereffect reduces the impact of unfavorable weather conditions on the formation of the pea yield from $30.11 \%$ to $28.1 \%$ [17]. It is believed that in comparison with conventional varieties, highly productive ones with the application of fertilizers, provide a yield increase of 3-4 times greater [18].

According to Kostromitin V. M. [et al.], pea makes good use of the aftereffect of organic and mineral fertilizers. Thus, placing pea after fertilized predecessors with the content of available forms of phosphorus and potassium of more than $15 \mathrm{mg}$ per $100 \mathrm{~g}$ of soil allows getting $3.0 \mathrm{t} / \mathrm{ha}$ of grain or more without applying mineral fertilizers. Also, under favorable weather conditions, the coefficients of use of nutrients from the soil increase: nitrogen - by $23-27 \%$, phosphorus - by $10 \%$, potassium - by $3-7 \%$, but the cropping capacity increase from the fertilizers application decreases by $0.6-1.0 \mathrm{t} / \mathrm{ha}$, compared to more arid conditions [19].

It was determined that varieties of the leafless morphotype have a lower protein content in the grain (19.9-24.2\%) compared to leaf varieties $(24.3-26.8 \%)$, but due to their higher yield capacity, they are able to provide protein harvest at the level of leaf varieties $-1.0-1.3 \mathrm{t} / \mathrm{ha}$ [20]. Therefore, it is important to achieve not only a high level of yield capacity, but also the corresponding indicators of grain quality. V. V.Lykhochvor's and M. A. Andrushko's research data confirm the possibility of simultaneous growth of cropping capacity and protein content in grain [9].

Thus, it is relevant to study the impact of the fertilization system and the possibilities of reducing the negative impact of unfavorable weather conditions on cropping capacity and grain quality. It is important to choose such varieties that, in addition to a high productivity potential, show the maximum response to fertilizers application and adaptive ability to the weather conditions of the growing region, which will ensure their more stable cropping capacity and quality indicators of grain. 
The purpose of the study is to establish the influence of the main fertilization system in crop rotation on the cropping capacity and quality of grain of mustachioed pea varieties under conditions of Eastern part of the Forest-Steppe of Ukraine.

Materials, methods and meteorological conditions. The research was conducted during 2016-2020 in a stationary nine-course system of grain-steam-tilling crop rotation of Plant Production Institute nd. a. V.Ya. Yuriev of NAAS with the following rotation of crops: autumn fallow - winter wheat - sugar beet - spring cereals - pea - winter wheat - corn for grain $(0.5$ of the field $)+$ soybean $(0.5$ of the fields $)$ - spring cereals - sunflower. After sunflower and under corn, manure was applied at a dose of $30 \mathrm{t} / \mathrm{h}$. It should be noted that since 2018 , sugar beet has been removed from the crop rotation and has been replaced with corn. Soil - chernozem typical medium humus slightly alkaline. The experiment scheme included three fertilization backgrounds: 1 - crop rotation (without fertilizers, which is formed under the influence of natural soil fertility); 2 organic background - application of $30 \mathrm{t} / \mathrm{ha}$ of manure in the field of autumn fallow and under corn, which is 6.6 tons per 1 ha of crop rotation area; 3 - organo-mineral (aftereffect of manure + $\mathrm{N}_{30} \mathrm{P}_{30} \mathrm{~K}_{30}$ in the main application). Mineral fertilizers in the form of NPK were applied under the main treatment, and manure - under autumn fallow and corn. Thus, pea plants used the nutrients of manure in the aftereffect on the fourth year.

During the period of studies on the background without basic fertilization, the content of easily hydrolyzed nitrogen in the arable layer per $100 \mathrm{~g}$ of soil was low or medium (13.2-17.8 mg), and mobile forms of phosphorus (12.9-10.3 mg) and potassium (10.6-11.2 mg) were increased. On the organic background, a high content of mobile forms of potassium (12.4-13.1 mg) was noted, and on the organo-mineral background with the application of $\mathrm{N}_{30} \mathrm{P}_{30} \mathrm{~K}_{30}-$ a high content of phosphorus (16.0-16.5 mg) and potassium (13.0-13.3 mg). At the same time, the indicators of nitrogen content were low or average.

The object of research is the zoned varieties Deviz, Tsarevych, Otaman, Oplot, Corvet, Haiduk and Malakhit. The technology of their cultivation was generally accepted for the eastern Forest-Steppe of Ukraine, with the exception of factors that were studied. The predecessor is spring grain crops. Sowing was carried out with Klen-1.5 M seed drill with a seeding rate of 1.2 million germinating seeds per hectare. Experiments were laid by the method of split plots, the placement of variants was systematic, the repetition was threefold, the total area of the plot was $37.5 \mathrm{~m}^{2}$, the accounting area was $25.0 \mathrm{~m}^{2}$. Observations, accountings and analyses in experiments were carried out according to generally accepted methods. The yield was harvested by direct threshing of plots with a "Sampo-130" combine. Statistical processing of the obtained experimental data was carried out by the method of variance analysis [21].

Weather conditions in 2016-2020 differed both in temperature and in the amount and distribution of precipitation. There were significant deviations of these indicators from the longterm average values. Spring in 2016 was early, excessively humid and warm. The amount of precipitation in April - May was 2-2.5 times higher than normal at increased temperature regime. The average daily temperature in March, April and May was 4.1, 3.3 and $0.9^{\circ} \mathrm{C}$ higher than normal, respectively. In June, there was a shortage of precipitation $-32 \%$ of the norm fell. At the same time, the sum of effective temperatures in April, May and June was 59.3, 67.6 and $63.2{ }^{\circ} \mathrm{C}$ higher than the long-term average indicators, respectively. In general, for five months (March-July), the amount of precipitation exceeded the norm by $120.3 \mathrm{~mm}$, and the temperature regime was higher by $1.1-1.9$ ${ }^{\circ} \mathrm{C}$.

In 2017 March was $5.4{ }^{\circ} \mathrm{C}$ warmer than usual, precipitation fell $20.5 \mathrm{~mm}$, which is 16.5 less than norm. However, the second half of April and May were cooler than norm by an average of $1.0-1.5^{\circ} \mathrm{C}$ with the amount of precipitation during this period of $116.4 \mathrm{~mm}$, which is at the level of norm $(119.8 \mathrm{~mm})$. The sum of effective temperatures in May was $20.0{ }^{\circ} \mathrm{C}$ less than the optimal level and was $195.0^{\circ} \mathrm{C}$. In June, the average daily temperature exceeded the norm by $1.4{ }^{\circ} \mathrm{C}$, and the amount of precipitation $(43.5 \mathrm{~mm})$ was $67 \%$ of norm. The temperature regime in July was 1.2 ${ }^{\circ} \mathrm{C}$ higher, and the amount of precipitation was $28.5 \mathrm{~mm}$, which is 2.3 times less than norm. In general, in March-July, the sum of effective temperatures was below norm, and precipitation was $125.2 \mathrm{~mm}$ or $59 \%$ of normal. 
The spring-summer period of 2018 was characterized as insufficiently humid with an increased temperature regime. April and May were 2.8 and $3.08{ }^{\circ} \mathrm{C}$ warmer, respectively. In March, precipitation $(109.3 \mathrm{~mm}$ ) was four times higher than norm, but for the period May - July, their total amount $(113.4 \mathrm{~mm})$ was 2.1 times less than norm, and the average monthly air temperature was $2.4-4.5^{\circ} \mathrm{C}$ higher than norm.

Hydrothermal conditions in 2019 were the most unfavorable for the formation of productivity of pea varieties. During April, air temperatures and precipitation were close to norm, but in May they exceeded the long-term average indicators by $10 \%$ and $60 \%$, respectively. In June, abnormally hot weather was observed with a lack of precipitation $(25.4 \mathrm{~mm}$ or $60 \%$ of norm) and an increase in the average daily air temperature by $4.3^{\circ} \mathrm{C}$. In the second decade of June, at the absence of precipitation, the maximum air temperatures were $34-37^{\circ} \mathrm{C}$, and on the soil surface $-60-65^{\circ} \mathrm{C}$, which led to soil and air droughts. Average daily temperatures in July and August were close to norm, but the amount of precipitation was only $27.4 \mathrm{~mm}$ and $10.6 \mathrm{~mm}$, or $38.2 \%$ and $22.6 \%$ of norm.

April 2020 was characterized by dry conditions and low air temperatures. However, the lack of precipitation was fully compensated in May $-176.1 \mathrm{~mm}$ fell, which is four times more than norm. At the same time, the average monthly temperature $\left(13.1{ }^{\circ} \mathrm{C}\right)$ was $3.0{ }^{\circ} \mathrm{C}$ less, which contributed to the increase in the vegetative mass of plants. In June, the average daily temperature $\left(21.3{ }^{\circ} \mathrm{C}\right)$ was $1.1{ }^{\circ} \mathrm{C}$ higher than norm with insufficient amount of precipitation. In July, at the increased temperature regime, the amount of precipitation was $107.8 \mathrm{~mm}$, which positively affected plant productivity. In August, the average daily air temperature exceeded the norm by $1.7^{\circ} \mathrm{C}$, and the amount of precipitation was only $12.8 \mathrm{~mm}$. So, in the years of research, weather conditions were contrasting in temperature and hydrothermal regime with an uneven distribution of precipitation during the growing season of pea varieties, which made it possible to more comprehensively assess the effectiveness of the fertilization system, which was studied in experiments.

Results and discussion. According to the results of our research, it was determined that on average for five years the highest grain cropping capacity on crop rotation background (without fertilizers) was provided by Tsarevych $(2.33 \mathrm{t} / \mathrm{ha})$, Haiduk $(2.28 \mathrm{t} / \mathrm{ha})$ and Oplot $(2.27 \mathrm{t} / \mathrm{ha})$ varieties, which is $0.19-0.25 \mathrm{t} / \mathrm{ha}$ higher than the standard Deviz variety $(2.08 \mathrm{t} / \mathrm{ha})$. Depending on the year of research, the maximum cropping capacity of these varieties ranged from 3.04-3.21 t/ha, the minimum $-0.77-0.88 \mathrm{t} / \mathrm{ha}$, and the range of variation was $2.27-2.38 \mathrm{t} / \mathrm{ha}$ (table 1 ). Significantly higher indicators of varieties productivity were obtained on fertilized nutrition backgrounds. Thus, against the background of the manure aftereffect, the highest yield $(2.75-2.77 \mathrm{t} / \mathrm{ha}) \mathrm{was}$ formed by Tsarevych, Haiduk and Oplot varieties, which exceeded the standard by an average of $0.43-0.45$ $\mathrm{t} /$ ha or $18.5-19.4 \%$. Compared to the unfertilized background, the grain growth in these varieties was $0.44-0.45 \mathrm{t} / \mathrm{ha}$ or $18.9-21.5 \%$. It should be noted that the smallest range of yield variation $(2.18 \mathrm{t} / \mathrm{ha})$ was observed in Tsarevych variety.

The maximum productivity of the studying varieties was provided at the main application of mineral fertilizers at a dose of $\mathrm{N}_{30} \mathrm{P}_{30} \mathrm{~K}_{30}$ against the background of manure aftereffect. Thus, the cropping capacity of Deviz variety was $2.69 \mathrm{t} / \mathrm{ha}$ or $0.61 \mathrm{t} / \mathrm{ha}$ higher than the control (without fertilizers). At the same time, Tsarevych, Haiduk and Oplot varieties were distinguished with a yield level of $3.17 \mathrm{t} / \mathrm{ha}, 3.07$ and $3.04 \mathrm{t} / \mathrm{ha}$, respectively, and a grain increase compared to the unfertilized background of $0.84 \mathrm{t} / \mathrm{ha}, 0.79$ and $0.77 \mathrm{t} / \mathrm{ha}$, which indicates a good reaction to the increased nutrition background and suitability for growing using intensive technology. The average annual maximum cropping capacity of these varieties was $4.16-4.39 \mathrm{t} / \mathrm{ha}$, the minimum $-1.27-1.51$ $\mathrm{t} / \mathrm{ha}$, and the range of its variation was the highest - from 2.79 to $2.89 \mathrm{t} / \mathrm{ha}$.

The smallest increase in grain on organo-mineral background of fertilization was obtained in Malakhit and Corvet varieties -0.47 and $0.56 \mathrm{t} / \mathrm{ha}$, respectively. At the same time, the range of cropping capacity variation over the years was the smallest $-2.43-2.44 \mathrm{t} /$ ha (table 1 ). The cropping capacity of pea grains varied not only depending on the biological peculiarities of the variety and the nutrition background, but also under the influence of weather conditions of the year. 
Table 1

Cropping capacity of pea varieties depending on the fertilization background, $t / h a$, 2016-2020

\begin{tabular}{|c|c|c|c|c|c|c|c|c|c|c|c|}
\hline \multirow{2}{*}{ Varieties(B) } & \multicolumn{5}{|c|}{ Years of research } & \multirow[t]{2}{*}{$\begin{array}{l}\text { Avera } \\
\text { ge,t/ha }\end{array}$} & \multicolumn{2}{|c|}{$\begin{array}{c}\text { Grain } \\
\text { increase }\end{array}$} & \multicolumn{3}{|c|}{$\begin{array}{c}\text { Cropping capacity, } \\
\text { t/ha }\end{array}$} \\
\hline & 2016 & 2017 & 2018 & 2019 & 2020 & & $\mathrm{t} / \mathrm{ha}$ & $\%$ & $\max$ & $\min$ & $\begin{array}{l}\text { Max - } \\
\min \end{array}$ \\
\hline \multicolumn{12}{|c|}{ without fertilizers (A) } \\
\hline Deviz - st. & 2,56 & 2,50 & 2,08 & 0,76 & 2,51 & 2,08 & - & - & 2,56 & 0,76 & 1,80 \\
\hline Tsarevych & 2,40 & 3,17 & 2,29 & 0,88 & 2,92 & 2,33 & 0,25 & 12,0 & 3,17 & 0,88 & 2,29 \\
\hline Otaman & 2,47 & 2,61 & 2,03 & 0,86 & 3,08 & 2,21 & 0,13 & 6,3 & 3,08 & 0,86 & 2,22 \\
\hline Oplot & 3,21 & 2,41 & 1,97 & 0,83 & 2,94 & 2,27 & 0,19 & 9,1 & 3,21 & 0,83 & 2,38 \\
\hline Corvet & 3,16 & 2,55 & 2,11 & 0,78 & 2,36 & 2,19 & 0,11 & 5,3 & 3,16 & 0,78 & 2,38 \\
\hline Haiduk & 2,60 & 3,04 & 2,26 & 0,77 & 2,75 & 2,28 & 0,20 & 9,6 & 3,04 & 0,77 & 2,27 \\
\hline Malakhit & 2,64 & 2,65 & 1,99 & 0,82 & 2,34 & 2,09 & 0,01 & 0,5 & 2,65 & 0,82 & 1,83 \\
\hline average & 2,72 & 2,70 & 2,24 & 0,81 & 2,70 & 2,21 & 0,13 & 6,3 & - & - & - \\
\hline \multicolumn{12}{|c|}{ background - manure aftereffect } \\
\hline Deviz - st. & 3,02 & 2,61 & 2,45 & 0,80 & 2,72 & 2,32 & - & - & 3,02 & 0,80 & 2,22 \\
\hline Tsarevych & 3,07 & 3,62 & 2,60 & 1,44 & 3,11 & 2,77 & 0,45 & 19,4 & 3,62 & 1,44 & 2,18 \\
\hline Otaman & 3,19 & 3,30 & 2,40 & 1,38 & 3,21 & 2,70 & 0,38 & 16,4 & 3,30 & 1,38 & 1,92 \\
\hline Oplot & 3,90 & 3,16 & 2,35 & 1,22 & 3,19 & 2,76 & 0,44 & 19,0 & 3,90 & 1,22 & 2,68 \\
\hline Corvet & 3,34 & 3,14 & 2,32 & 1,19 & 2,55 & 2,51 & 0,19 & 8,2 & 3,34 & 1,19 & 2,15 \\
\hline Haiduk & 3,19 & 3,70 & 2,67 & 1,29 & 2,88 & 2,75 & 0,43 & 18,5 & 3,70 & 1,29 & 2,41 \\
\hline Malakhit & 2,77 & 3,12 & 2,25 & 1,06 & 2,42 & 2,32 & 0,00 & 0,0 & 3,12 & 1,06 & 2,06 \\
\hline average & 3,21 & 3,23 & 2,43 & 1,20 & 2,87 & 2,59 & 0,32 & 11,6 & - & - & - \\
\hline \multicolumn{12}{|c|}{ background $+\mathrm{N}_{30} \mathrm{P}_{30} \mathrm{~K}_{30}$} \\
\hline Deviz - st. & 3,57 & 3,26 & 2,62 & 1,01 & 2,97 & 2,69 & - & - & 3,57 & 1,01 & 2,56 \\
\hline Tsarevych & 3,61 & 4,39 & 2,87 & 1,51 & 3,46 & 3,17 & 0,48 & 17,8 & 4,39 & 1,51 & 2,88 \\
\hline Otaman & 3,66 & 3,92 & 2,50 & 1,41 & 3,57 & 3,01 & 0,32 & 11,9 & 3,92 & 1,41 & 2,51 \\
\hline Oplot & 4,16 & 3,83 & 2,47 & 1,27 & 3,48 & 3,04 & 0,35 & 13,0 & 4,16 & 1,27 & 2,89 \\
\hline Corvet & 3,70 & 3,60 & 2,43 & 1,26 & 2,78 & 2,75 & 0,06 & 2,2 & 3,70 & 1,26 & 2,44 \\
\hline Haiduk & 3,63 & 4,17 & 3,00 & 1,38 & 3,15 & 3,07 & 0,38 & 14,1 & 4,17 & 1,38 & 2,79 \\
\hline Malakhit & 3,04 & 3,61 & 2,40 & 1,18 & 2,57 & 2,56 & $-0,13$ & $-4,8$ & 3,61 & 1,18 & 2,43 \\
\hline average & 3,62 & 3,83 & 2,61 & 1,29 & 3,14 & 2,90 & 0,24 & 9,0 & - & - & - \\
\hline \multicolumn{12}{|c|}{ average by nutrition background } \\
\hline Deviz - st. & 3,05 & 2,79 & 2,38 & 0,86 & 2,73 & $2,36^{\circ}$ & - & - & 3,05 & 0,86 & 2,19 \\
\hline Tsarevych & 3,03 & 3,73 & 2,59 & 1,27 & 3,16 & 2,76 & 0,40 & 16,9 & 3,73 & 1,27 & 2,46 \\
\hline Otaman & 3,11 & 3,28 & 2,31 & 1,22 & 3,29 & 2,64 & 0,28 & 11,9 & 3,29 & 1,22 & 2,07 \\
\hline Oplot & 3,76 & 3,13 & 2,26 & 1,11 & 3,20 & 2,69 & 0,33 & 14,0 & 3,76 & 1,11 & 2,65 \\
\hline Corvet & 3,40 & 3,10 & 2,29 & 1,08 & 2,56 & 2,49 & 0,13 & 5,5 & 3,40 & 1,08 & 2,32 \\
\hline Haiduk & 3,14 & 3,64 & 2,64 & 1,15 & 2,93 & 2,70 & 0,34 & 14,4 & 3,64 & 1,15 & 2,49 \\
\hline Malakhit & 2,82 & 3,13 & 2,21 & 1,02 & 2,44 & 2,32 & $-0,04$ & 0,02 & 3,13 & 1,02 & 2,11 \\
\hline average & 3,19 & 3,26 & 2,38 & 1,10 & 2,90 & 2,57 & 0,24 & 9,3 & - & - & - \\
\hline
\end{tabular}

$\mathrm{LSD}_{05}$ t/ha: $2016 \mathrm{~A}-0,24 ; \mathrm{B}-0,32 ; \mathrm{AB}-0,64$

$2017 \mathrm{~A}-0,16 ; \mathrm{B}-0,24 ; \mathrm{AB}-0,42$

$2018 \mathrm{~A}-0,16 ; \mathrm{B}-0,19 ; \mathrm{AB}-0,22$

$2019 \mathrm{~A}-0,15 ; \mathrm{B}-0,14 ; \mathrm{AB}-0,23$

$2020 \mathrm{~A}-0,12 ; \mathrm{B}-0,16 ; \mathrm{AB}-0,23$

Sharp fluctuations in the hydrothermal regime had a significant impact on the production process of varieties, and changes in the formation of biomass, especially in dry years, adequately affected grain cropping capacity. The best weather conditions for the growing season for the studying varieties were in 2016, 2017 and 2020, in which the average cropping capacity of varieties 
was accordingly on the control (without fertilizers) $2.70-2.72 \mathrm{t} / \mathrm{ha}$, against the background of manure aftereffect $-2.87-3.23 \mathrm{t} / \mathrm{ha}$, against the background of manure aftereffect $+\mathrm{N}_{30} \mathrm{P}_{30} \mathrm{~K}_{30}-$ 3.14-3.83 t/ha. Among the varieties, the highest productivity was provided by: against the background without fertilizers - Oplot (3.21 t/ha - in 2016), Tsarevych ( $3.17 \mathrm{t} / \mathrm{ha}$ - in 2017) and Otaman (3.08 t/ha - in 2020); against the background of manure aftereffects - Oplot (3.90 t/ha), Haiduk ( $3.70 \mathrm{t} / \mathrm{ha}$ ) and Otaman (3.21 t/ha); on organo-mineral background - Oplot $(4.16 \mathrm{t} / \mathrm{ha})$, Tsarevych (4.39 t/ha) and Otaman (3.57 t/ha). It should be noted that for all the years of research among these varieties, the smallest range of cropping capacity variation was observed in Otaman variety, which, depending on the nutrition background, was $1.92-2.56 \mathrm{t} / \mathrm{ha}$.

In 2018, according to the studying fertilization options, the cropping capacity of all varieties decreased on average to the level of $2.24 \mathrm{t} / \mathrm{ha}, 2.43$ and $2.61 \mathrm{t} / \mathrm{ha}$, which is due to insufficient amount of precipitation during May - July (2.1 times less than norm) and increased temperature regime during this period $\left(+2.4-4.5{ }^{\circ} \mathrm{C}\right.$ to the long-term average data). It should be noted that the lowest reaction to arid conditions and a decrease in their negative impact on plant productivity was determined in Tsarevych and Haiduk varieties, as evidenced by the highest level of their cropping capacity on all nutrition backgrounds: on control (without fertilizers) -2.29 and $2.26 \mathrm{t} / \mathrm{ha}$, respectively; against the background of manure aftereffect $-2.60-2.67 \mathrm{t} / \mathrm{ha}$; on organo-mineral background $-2.87-3.00 \mathrm{t} / \mathrm{ha}$.

But the most unfavorable weather conditions for the formation of pea productivity were in 2019. They were the most critical in June due to a lack of precipitation and a sharp increase in air temperature $\left(+4.3^{\circ} \mathrm{C}\right.$ to norm). Abnormally dry was the second decade of June, when air and soil droughts led to a violation of water balance, suspension of the growth of plant biomass, reduction of formation and beans filling processes, violation of the intake of plastic substances, premature ripening of grain and a decrease in its mass. Prolonged soil drought was observed before harvesting. Under such arid conditions in 2019, regardless of the nutrition background, Tsarevych and Otaman varieties were the most resistant to drought, which indicates their high adaptive capacity. Thus, on the control, their cropping capacity was 0.88 and $0.86 \mathrm{t} / \mathrm{ha}$, respectively, against the background of manure aftereffect -1.44 and $1.38 \mathrm{t} / \mathrm{ha}$, against the background of manure $+\mathrm{N}_{30} \mathrm{P}_{30} \mathrm{~K}_{30}-1.51$ and $1.41 \mathrm{t} / \mathrm{ha}$. At the same time, the average cropping capacity for varieties on an unfertilized background was $0.81 \mathrm{t} / \mathrm{ha}$, and on organic (manure aftereffect) and organo-mineral (manure aftereffect $+\mathrm{N}_{30} \mathrm{P}_{30} \mathrm{~K}_{30}$ ), significant grain increases were obtained $-0.39 \mathrm{t} / \mathrm{ha}$ and $0.48 \mathrm{t} / \mathrm{ha}$, respectively.

Thus, on average for 2016'2020, Tsarevych and Haiduk varieties reacted best to fertilizers application, which provided a consistently high grain growth: against the background of a manure aftereffect of 0.44 and $0.47 \mathrm{t} / \mathrm{ha}$, respectively, and at $\mathrm{N}_{30} \mathrm{P}_{30} \mathrm{~K}_{30}$ application against the background of a manure aftereffect -0.84 and 0.79 t/ha. On average over the varieties, organic and organomineral nutrition backgrounds provided an increase in grain yield of 0.38 and $0.69 \mathrm{t} / \mathrm{ha}$, respectively, with a cropping capacity of $2.21 \mathrm{t} / \mathrm{ha}$ on the control.

Taking into account the problem of fodder and food protein production, along with an increasing in pea productivity, great importance is given to grain quality indicators, which largely depend on the variety, growing area, soil, weather conditions and elements of cultivation technology $[9,22,23,24]$.

According to the results of the analysis for three years, the highest protein content in grain was formed in 2020 - on average for varieties on organo-mineral background (manure aftereffect + $\mathrm{N}_{30} \mathrm{P}_{30} \mathrm{~K}_{30}$ ), it was $23.34 \%$ with fluctuations between $22.58-24.63 \%$, and on the control $-23.06 \%$ (in the range from 22.27 to $24.09 \%$ ). This was facilitated by the increased average daily temperature in June and the first half of July with insufficient amount of precipitation, as well as a favorable temperature regime in the preharvest period. The difference in grain quality was found not only in the nutrition background, but also in varieties. The highest protein content in grain was contained in Corvet and Malakhit varieties with indicators of 24.09 and $23.35 \%$, respectively, on the control and 24.63 and $23.39 \%$ - on organo-mineral background of fertilization. At the same time, the cropping capacity of Malakhit and Corvet varieties on both backgrounds was the lowest $-2.34-2.36 \mathrm{t} / \mathrm{ha}$ and 2.56-2.75 t/ha, respectively (table 2 ). 
Table 2

Protein content in the grain of pea varieties depending on the nutrition background, $\%, 2018-2020$

\begin{tabular}{cccccc}
\hline \multirow{2}{*}{ Variety } & \multicolumn{3}{c}{ Protein content, \% } & Average & $\begin{array}{c}\text { Increase, \% }( \pm) \\
\text { to standard }\end{array}$ \\
\cline { 2 - 3 } & 2018 & 2019 & 2020 & \\
Deviz - standard & 19,25 & 21,53 & 22,87 & 21,22 & - \\
Tsarevych & 19,62 & 21,58 & 22,80 & 21,33 & $+0,11$ \\
Otaman & 18,93 & 21,61 & 22,72 & 21,09 & $-0,13$ \\
Oplot & 20,14 & 20,41 & 22,66 & 21,07 & $-0,15$ \\
Corvet & 21,92 & 21,30 & 24,09 & 22,44 & $+1,22$ \\
Haiduk & 20,69 & 20,87 & 22,95 & 21,50 & $+0,28$ \\
Malakhit & 22,09 & 20,86 & 23,35 & 22,10 & $+0,88$ \\
average & 20,38 & 21,17 & 23,06 & 21,54 & - \\
\hline manure aftereffect $+\mathrm{N}_{30} \mathrm{P}_{30} \mathrm{~K}_{30}$ & & \\
Deviz - standard & 19,55 & 23,02 & 22,58 & 21,72 & - \\
Tsarevych & 19,52 & 22,28 & 22,70 & 21,50 & $-0,22$ \\
Otaman & 19,42 & 22,51 & 23,55 & 21,83 & $+0,11$ \\
Oplot & 19,82 & 21,02 & 22,95 & 21,26 & $-0,46$ \\
Corvet & 21,60 & 22,71 & 24,63 & 22,98 & $+1,26$ \\
Haiduk & 21,07 & 22,66 & 23,55 & 22,43 & $+0,71$ \\
Malakhit & 21,05 & 22,38 & 23,39 & 22,27 & $+0,55$ \\
average & 20,29 & 22,37 & 23,34 & 22,00 & - \\
\hline LSD $05, \%$ for factors: & $\mathrm{A}-0,11$ & $\mathrm{~A}-0,12$ & $\mathrm{~A}-0,11$ & - & - \\
$\mathrm{A}-$ variety & $\mathrm{B}-0,15$ & $\mathrm{~B}-0,16$ & $\mathrm{~B}-0,13$ & & \\
B-nutrition background & $\mathrm{AB}-0,19$ & $\mathrm{AB}-0,22$ & $\mathrm{AB}-0,26$ & & \\
\hline
\end{tabular}

The lowest protein content of pea grain was detected in 2018 and averaged $20.38 \%$ for varieties on the control and $20.29 \%$ on fertilized organo - mineral background. The main reason for the decrease in protein indicators in grain was the increased average monthly air temperature $(+$ 2.4-4.5 ${ }^{\circ} \mathrm{C}$ ) and half the amount of precipitation $(113.4 \mathrm{~mm})$ for the period May-July. It should be noted that the highest protein content in grain was formed by the least productive varieties Corvet and Malakhit with indicators of 21.92 and $23.35 \%$ on the control variant and 21.05 and $21.6 \%$ on the fertilized one.

On average, over three years, the highest protein content in grain was provided by Corvet variety with indicators on control (without fertilizers) and organo-mineral (manure aftereffect + $\mathrm{N}_{30} \mathrm{P}_{30} \mathrm{~K}_{30}$ ), respectively, $22.44 \%$ and $22.98 \%$, which is 1.22 and $1.26 \%$ higher than Deviz (standard) variety.

In our experiments, the possibility of simultaneous growth of cropping capacity and protein content in grain, which was provided by the Haiduk variety, has been established. These indicators were lowest in Oplot variety. So, on average, for three years against the background of the manure aftereffect $+\mathrm{N}_{30} \mathrm{P}_{30} \mathrm{~K}_{30}$, compared to the standard Deviz variety, grain increase in Haiduk variety was $0.35 \mathrm{t} / \mathrm{ha}$, and the protein increase was $0.71 \%$, while in Oplot variety at an increase in cropping capacity by $0.25 \mathrm{t} / \mathrm{ha}$, the protein content decreased by $0.46 \%$.

An increase in grain protein content simultaneously with a high level of cropping capacity is an additional reserve for increasing the gross protein harvest. It should be noted that in all the years of research, fertilizers application contributed to an increase in protein harvest from 1 ha of a sowing area. On average, for 2018-2020, against the background of the manure aftereffect + $\mathrm{N}_{30} \mathrm{P}_{30} \mathrm{~K}_{30}$, protein harvest in the studying varieties was $0.638 \mathrm{t} / \mathrm{ha}$, which is 0.171 or $36.6 \%$ more compared to the control. The most significant gross protein harvest against the background without fertilizers was obtained in Tsarevych, Corvet and Haiduk varieties $-0.490-0.497 \mathrm{t} / \mathrm{ha}$, which is $11.1-12.7 \%$ more than the standard Deviz variety (table 3 ). 
Table 3

Gross protein harvest of pea varieties depending on the nutrition background, $t / h a$, 2018-2020

\begin{tabular}{|c|c|c|c|c|c|c|}
\hline \multirow{3}{*}{ Variety (A) } & \multicolumn{6}{|c|}{ Nutrition background (B) } \\
\hline & \multirow{2}{*}{$\begin{array}{l}\text { control } \\
\text { (without } \\
\text { fertilizers) }\end{array}$} & \multicolumn{2}{|c|}{ protein increase } & \multirow{2}{*}{$\begin{array}{c}\text { manure } \\
\text { aftereffect }+ \\
\mathrm{N}_{30} \mathrm{P}_{30} \mathrm{~K}_{30}\end{array}$} & \multicolumn{2}{|c|}{ protein increase } \\
\hline & & $\mathrm{t} / \mathrm{ha}$ & $\%$ & & t/ha & $\%$ \\
\hline Deviz - standard & 0,441 & - & - & 0,584 & - & - \\
\hline Tsarevych & 0,497 & 0,056 & 12,7 & 0,682 & 0,098 & 16,8 \\
\hline Otaman & 0,462 & 0,021 & 4,8 & 0,657 & 0,073 & 12,5 \\
\hline Oplot & 0,478 & 0,037 & 8,4 & 0,687 & 0,103 & 17,6 \\
\hline Corvet & 0,491 & 0,050 & 11,3 & 0,632 & 0,048 & 8,2 \\
\hline Haiduk & 0,490 & 0,049 & 11,1 & 0,689 & 0,105 & 17,8 \\
\hline Malakhit & 0,462 & 0,021 & 4,8 & 0,570 & $-0,014$ & $-2,4$ \\
\hline average & 0,467 & - & - & 0,638 & - & - \\
\hline \multicolumn{7}{|c|}{$\mathrm{LSD}_{05}, \mathrm{t} / \mathrm{ha}$ for factors: $\mathrm{A}-0,019 ; \mathrm{B}-0,022 ; \mathrm{AB}-0,034$} \\
\hline
\end{tabular}

On organo-mineral background, Haiduk, Oplot and Tsarevych varieties clearly distinguished with indicators of $0.682-0.689 \mathrm{t} / \mathrm{ha}$ and an increase in protein harvest of $16.8-17.8 \%$. At the same time, these varieties on both nutrition backgrounds provided the highest level of productivity. Therefore, the increase in gross protein harvest to a greater extend depended on the level of cropping capacity of pea varieties than on the protein content in the grain.

Conclusions. At unstable weather conditions, on average for five years on the control (without fertilizers), the highest grain yield was provided by Tsarevych $(2.33 \mathrm{t} / \mathrm{ha})$, Haiduk $(2.28$ $\mathrm{t} / \mathrm{ha}$ ) and Oplot (2.27 t/ha) varieties, which is $0.19-0.25 \mathrm{t} / \mathrm{ha}$ higher than the standard Deviz variety. Depending on the year of research, the maximum cropping capacity of these varieties ranged from $3.04-3.21 \mathrm{t} / \mathrm{ha}$, the minimum $-0.77-0.88 \mathrm{t} / \mathrm{ha}$, and the range of variation was $2.27-2.38 \mathrm{t} / \mathrm{ha}$. Against the background of the manure aftereffect, the productivity of these varieties $(2.75-2.77$ $\mathrm{t} / \mathrm{ha}$ ) exceeded the standard by an average of $0.43-0.45 \mathrm{t} / \mathrm{ha}$. Compared to the unfertilized background, grain growth was $0.44-0.45 \mathrm{t} / \mathrm{ha}$ or $18.9-21.5 \%$. Tsarevych variety had the smallest range of yield variations $(2.18 \mathrm{t} / \mathrm{ha})$.

At the main application of $\mathrm{N}_{30} \mathrm{P}_{30} \mathrm{~K}_{30}$ against the background of manure aftereffect, the maximum productivity (3.04-3.07 and $\mathrm{t} / \mathrm{ha})$ and grain increase $(0.77-0.84 \mathrm{t} / \mathrm{ha})$ were provided by Tsarevych, Haiduk and Oplot varieties, which indicates their high reaction to fertilization and suitability for growing using intensive technology. The average annual maximum cropping capacity of these varieties was 4.16-4.39 $\mathrm{t} / \mathrm{ha}$, the minimum $-1.27-1.51 \mathrm{t} / \mathrm{ha}$, and the range of its variation was the highest - from 2.79 to $2.89 \mathrm{t} / \mathrm{ha}$. The smallest increase in grain on organo-mineral background of fertilization was obtained in Malakhit and Corvet varieties -0.47 and $0.56 \mathrm{t} / \mathrm{ha}$, respectively. At the same time, the range of cropping capacity variation over the years was the smallest $-2.43-2.44 \mathrm{t} / \mathrm{ha}$

The best weather conditions for the growing season were in 2016, 2017 and 2020, which provided, accordingly, the highest level of average cropping capacity of varieties by nutrition backgrounds: without fertilizers $-2.70-2.72 \mathrm{t} / \mathrm{ha}$, manure aftereffect $-2.87-3.23 \mathrm{t} / \mathrm{ha}$, manure aftereffect $+\mathrm{N}_{30} \mathrm{P}_{30} \mathrm{~K}_{30}-3.14-3.83 \mathrm{t} / \mathrm{ha}$. In the driest conditions of 2019, regardless of the nutrition background, Tsarevych and Otaman varieties were the most resistant to drought, which indicates their high adaptive capacity. At the same time, the average cropping capacity for varieties on an unfertilized background was $0.81 \mathrm{t} / \mathrm{ha}$, and organic (manure aftereffect) and organo-mineral nutrition background provided significant grain increases $-0.39 \mathrm{t} / \mathrm{ha}$ and $0.48 \mathrm{t} / \mathrm{ha}$, respectively.

On average, for 2016-2020, Tsarevych and Haiduk varieties reacted best to fertilizers application, the grain increase of which to the control were consistently high -0.44 and $0.47 \mathrm{t} / \mathrm{ha}$, respectively, against the background of manure aftereffect, and 0.84 and $0.79 \mathrm{t} / \mathrm{ha}-$ at an additional application of $\mathrm{N}_{30} \mathrm{P}_{30} \mathrm{~K}_{30}$. Over the years of research, on average for varieties, organic and organo- 
mineral nutrition backgrounds provided a significant increase in grain - by 0.38 and $0.69 \mathrm{t} / \mathrm{ha}$, respectively, with a cropping capacity of $2.21 \mathrm{t} / \mathrm{ha}$ on the control.

The difference in grain quality has been revealed depending on the variety and nutrition background. The highest protein content of grain was provided by the least productive varieties Corvet and Malakhit with indicators of 24.09 and $23.35 \%$ on the control and 24.63 and $23.39 \%$ on organo - mineral nutrition background, respectively. The possibility of simultaneous growth of cropping capacity and protein content in grain of Haiduk variety has been established. The most significant gross protein harvest was obtained on organo-mineral background in Haiduk, Oplot and Tsarevych varieties $(0.682-0.689 \mathrm{t} / \mathrm{ha})$ with an increase of $16.8-17.8 \%$ to the standard Deviz variety. The increase in gross protein harvest per hectare in most varieties depended more on the level of their cropping capacity than on the protein content in the grain.

\section{Список використаних джерел}

1. Вавилов П. П., Посыпанов Г.С. Бобовые культуры и проблемы растительного белка. М., 1983. C. 255.

2. Камінський В.Ф. Стан і перспективи виробництва гороху в Україні. Вісник аграрної науки. 2000. № 5. С. 22-25.

3. Жуйков О.Г., Лагутенко К.В. Горох посівний в Україні - стан, проблеми, перспективи. Таврійський науковий вісник: землеробство, рослинництво, овочівництво та баштанниитво. 2017. № 98. С. 65-97.

4. Зинченко А.И., Карасюк И. М. Интенсивная технология возделывания зерновых и технических культур. Киев: Головное издательство издательского объединения «Вища школа», 1988. С. 231-254.

5. Кобизєва Л.Н., Буряк Ю.І., Коломацька В.П., Кириченко В.В., Попов С.І. та ін. Каталог сортів і гібридів польових культур селекції Інституту рослинництва ім. В.Я. Юр'єва НААН. Видання четверте, доповнене. Харків: ІР НААН, 2021. 192 с.

6. Гирка А.Д., Ткаліч І.Д., Сидоренко Ю.Я та ін. Особливості формування зернової продуктивності різних сортів гороху в умовах Північного Степу України. Зернові культури. 2018. Том 2. № 2. С. 267-273. DOI: 10.31867/2523-4544/0035.

7. Телекало Н.В. Вплив комплексу технологічних прийомів на вирощування гороху посівного. Сільське господарство та лісництво. 2019. Випуск 13. С. 84-93.

8. Камінський В. Ф., Дворецька С. П., Костина Т.П. Вплив погодних умов та системи удобрення на формування продуктивності сортів гороху. 3б. наук. пр. ННЦ «Інститут землеробства УААН». 2012. Вип. 3-4. С. 82-90.

9. Лихочвор В.В., Андрушко М.О. Продуктивність гороху залежно від сорту та норм висіву. Вісник аграрної науки Причорномор'я. 2020. Вип. 2. С. 54-62. DOI:10.31521/2313092X/2020-2(106)-6.

10. Гайдукевич Л.И. Питание бобовых. М.: Знание. 1965. 32 с.

Ошибка! Источник ссылки не найден.. Цибулько В.С., Буряк Ю.І., Попов С.І., Чернобаб О.В. Горох, вика озима, люцерна. Нове в технології вирощування на насіння. Харків, 2000. $96 \mathrm{c}$.

12.Фатеев А.И. Локальный способ внесения удобрений. Почвенно-агрохимические аспекты. Харьков. 2002. 160 с.

13. Целуйко О.А., Парамонов А.В. Влияние длительного применения удобрений на урожайность гороха. Зернобобовые и крупяныле культурыл. 2019. № 4(32). С. 46-51.

14. Господаренко Г.М. Удобрення сільськогосподарських культур. К.: ТОВ «СІК ГРУП УКРАЇНА», 2016. $276 \mathrm{c.}$

15. Гамаюнова В.В., Туз М.С. Вплив елементів технології вирощування на продуктивність сортів гороху в Південному Степу. Збірник наукових праць ННЦ «Інститут землеробства HAAH». 2016. № 1. С. 46-57.

16. Заришняк А.С., Цвей Я.П., Іваніна В.В. Оптимізація удобрення та родючості грунту у сівозмінах. за ред. А.С. Заришняка. К. : Аграрна наука, 2015. 208 с. 
17. Бурикіна С.I. Вельвер М.О. Капустіна Г.А. Агрономічна ефективність добрив при вирощуванні гороху в умовах змін клімату причорноморського степу. Таврійський науковий вісник: 2020. Вип. 114. С. 33-43. DOI: 10.32851/2226-0099.2020.114.5.

18. Парохин Н.В., Хмелин А.В. Значение современных сортов в повышении эффективности сельскохозяйственного производства. Роль современных сортов и технологий в сельскохозяйственном производстве. Орел: ОрелГАУ, 2005. С. 94-104.

19. Костромітін В.М., Стрельцова І.Б., Огурцов Ю.С., Кисельова Н.В. Винос поживних речовин сортами гороху різного морфотипу. Селеки̧ія $і$ насінництво. 2006. Вип. 92. С. $213-$ 222.

20. Огурцов Ю.С., Рогуліна Л.В. Вплив добрив на урожайність та збір білка сортів гороху різного морфотипу. Корми і кормовиробництво. 2006. Вип. 57. С. 162-166.

21. Доспехов Б.А. Методика полевого опыта (с основами статистической обработки результатов исследований). М. : Агропромиздат, 1985. 351 с.

22. Василенко А.О., Безуглий I.М., Глянцев А.В. та ін. Стабільність показників продуктивності і вмісту білка у сортів гороху селекції Інституту рослинництва ім. В.Я. Юр'єва. Збірник наукових пращь Селекиійно-генетичного інституту - національного иентру насінництва і селекиії. 2015. Вип. 26(66). С. 154-160.

23. Кушнір О.М. Оцінка показників якості зерна гороху залежно від впливу технологічних прийомів. Корми та кормовиробництво. 2005. Вип. 55. С. 121-128.

24. Черенков А.В., Клиша А.І., ГиркаА.Д., Кулініч О.О. Зернобобові культури: сучасні технології вирощування: монографія; за ред. А.В. Черенкова. Дніпропетровськ: Акцент ПП, 2014. 110 c.

\section{References}

1. Vavilov PP, Posypanov GS. Legumes and vegetable protein problems. Moscow, 1983. 255 p.

2. Kaminskyi VF. Status and prospects of pea production in Ukraine. Bulletin of Agricultural Science. 2000; 5: 22-25.

3. Zhuikov AG, Lahutenko KV. Green peas in Ukraine: state, problems, prospects (a review article). Tavriiskyi naukovyi visnyk: zemlerobstvo, roslynnytstvo, ovochivnytstvo ta bashtannytstvo. 2017; 98: 65-97.

4. Zynchenko AY, Karasiuk YM. Intensive technology of cultivation of grain and industrial crops. Kyiv: Holovnoe yzdatelstvo yzdatelskoho ob'edynenyia «Vyshcha shkola», 1988. P. 231-254.

5. Kobyzieva LN, Buriak YuI, Kolomatska VP et al. Catalog of varieties and hybrids of field crops of Plant Production Institute nd. a. V.Ya. Yuryiv. Kharkiv: PPI of NAAS, 2021, 191 p.

6. Gyrka AD, Tkalich ID, Sydorenko YuYa, Bochevar OV, Ilyenko OV. Features of formation the grain productivity of pea varieties in conditions of the Northern Steppe of Ukraine. Zernovi kultury. 2018; 2(2): 267-273. DOI: https://doi.org/10.31867/2523-4544/0035.

7. Telecalo NV. Influence of the complex of technological administrations on the growth of the peas of general. Silske hospodarstvo ta lisnytstvo. 2019; 13: 84-93.

8. Kaminskyi VF, Dvoretska SP, Kostyna TP. Influence of weather conditions and fertilizer system on the formation of productivity of pea varieties. Zbirnyk naukovykh prats NNTs «Instytut zemlerobstva NAAN». 2012; 3-4: 82-90.

9. Lykhochvor V, Andrushko M. Pea productivity depending on variety and sowing rate. Visnyk ahrarnoi nauky Prychornomoria. 2020; 2: 54-62. DOI: 10.31521/2313-092X/2020-2(106)-6.

10. Haidukevych LY. Legume nutrition. Moscow: Znanye, 1965, 32 p.

11. Tsybulko VS, Buriak YuI, Popov SI, Chernobab OV. Peas, winter wheat, alfalfa. New in seed growing technology. Kharkiv, 2000, 96 p.

12. Fateev AY. Local method of fertilizing. Soil-agrochemical aspects. Kharkov, 2002, $160 \mathrm{p}$.

13. Tseluiko OA, Paramonov AV. The influence of long-term use of fertilizers on the yield of peas. Zernobobovye y krupianye kultury. 2019; 4(32): 46-51.

14. Hospodarenko HM. Fertilization of agricultural crops. Kyiv: TOV «SIK HRUP UKRAINA»: 2016, $276 \mathrm{p}$. 
15. Hamaiunova VV, Tuz MS. Influence of elements of cultivation technology on productivity of pea varieties in the Southern Steppe. Zbirnyk naukovykh prats NNTs «Instytut zemlerobstva NAAN». 2016; 1: 46-57.

16. Zaryshniak AS, Tsvei YaP, Ivanina VV. Optimization of fertilizer and soil fertility in crop rotations. Kyiv: Ahrarna nauka, 2015. 208 p.

17. Burykina SI, Welver MO, Kapustina GA. Agronomic efficiency of fertilizers in pea growing under the conditions of climate change of the Black Sea Steppe. Tavriiskyi naukovyi visnyk. 2020; 114: 33-43. DOI: https://doi.org/10.32851/2226-0099.2020.114.5.

18. Parokhin NV, Khmelin AV. The value of modern varieties in improving the efficiency of agricultural production. The role of modern varieties and technologies: Proceedings of the AllRussian Scientific and Practical Conference on June 12-15, 2004. Orel: OrelHAU, 2005. P. 94-104.

19. Kostromitin VM, Streltsova IB, Ohurtsov YuYe, Kyselova NV. Removal of nutrients by pea varieties of different morphotypes. Sel. Nasinn. 2006; 92: 213-222.

20. Ohurtsov YuYe, Rohulina LV. Influence of fertilizers on yield and protein collection of pea varieties of different morphotype. Kormy i kormovyrobnytstvo. 2006; 57: 162-166.

21. Dospekhov BA. Field experiment methodology (with the basics of statistical processing of the research results). Moscow: Ahropromizdat, 1985.351 p.

22. Vasylenko AO, Bezuhlyi IM, Hliantsev AV et al. Stability of productivity and protein content in pea varieties selected by the Plant Production Institute nd. a. V.Ya. Yuryev. Zbirnyk naukovykh prats Selektsiino-henetychnoho instytutu - natsionalnoho tsentru nasinnytstva i selektsii. 2015; 26(66): 154-160.

23. Kushnir OM. Evaluation of pea grain quality indicators depending on the influence of technological methods. Kormy i kormovyrobnytstvo. 2005; 55: 121-128.

24. Cherenkov AV, Klysha AI, Hyrka AD, Kulinich OO. Legumes: modern cultivation technologies. Dnipropetrovsk: Aktsent PP, 2014. 110 p.

\section{ПРОДУКТИВНІСТЬ ВУСАТИХ СОРТІВ ГОРОХУ ЗАЛЕЖНО ВІД ФОНУ ЖИВЛЕННЯ В УМОВАХ СХІДНОГО ЛІСОСТЕПУ УКРАЇНИ}

Попов С.I., Глубокий О.М.

Інститут рослинництва ім. В.Я. Юр’єва НААН, Україна

Мета дослідження - встановити вплив системи основного удобрення в сівозміні на врожайність і якість зерна вусатих сортів гороху в умовах східної частини Лісостепу України.

Матеріали і методи. Дослідження проводили протягом 2016-2020 рр. у стаціонарній дев'ятипільній зерно-паро-просапній сівозміні IP ім. В.Я. Юр'єва НААН. Грунт чорнозем типовий середньогумусний слабковилужений. Об'єктом дослідження були сім сортів гороху вусатого типу - Девіз, Царевич, Отаман, Оплот, Корвет, Гайдук и Малахіт. Схема досліду включала три фони удобрення: 1 - сівозмінний (без добрив); 2 органічний фон; 3 - органо-мінеральний (післядія гною $+\mathrm{N}_{30} \mathrm{P}_{30} \mathrm{~K}_{30}$ в основне внесення). Технологія вирощування - загальноприйнята для зони. Статистичну обробку експериментальних результатів проводили за дисперсійним аналізом.

Обговорення результатів. У нестабільних погодних умовах 2016-2020 pp. на сівозмінному фоні (без добрив) найвищий рівень урожайності забезпечили сорти Царевич $(2,33$ т/га), Гайдук (2,28 т/га) і Оплот (2,27 т/га), що на 0,19-0,25 т/га вище стандартного сорту Девіз. Залежно від року досліджень максимальна урожайність цих сортів коливалася в межах 3,04-3,21 т/га, мінімальна - 0,77-0,88 т/га, а розмах варіації становив 2,27-2,38 т/га. На органічному фоні врожайність цих сортів (2,75-2,77 т/га) перевищували стандарт у середньому на $0,43-0,45$ т/га, а в порівнянні з неудобреним фоном прибавка врожайності у зазначених сортів склав 0,44-0,45 т/га або 18,9-21,5 \%. 
Найбільш високою була врожайність (3,04-3,07 т/га) і прибавку $(0,77-0,84$ т/га) забезпечили сорти Царевич, Гайдук і Оплот на органо-мінеральному фоні, що свідчить про їх хорошу реакцію на підвищений фон живлення та придатність до вирощування за інтенсивною технологією. Середньорічна максимальна врожайність зазначених сортів становила 4,164,39 т/га,, мінімальна - 1,27-1,51 т/га, а розмах її варіювання був найвищий - від 2,79 до 2,89 т/га. Найменший приріст урожайності на органо-мінеральному фоні удобрення одержано у сортів Малахіт і Корвет $-0,47$ та 0,56 т/га відповідно. При цьому розмах варіації врожайності за роками був найменшим - 2,43-2,44 т/га.

Найкращі погодні умови за вегетаційний період для досліджуваних сортів склалися у 2016, 2017 та 2020 рр., що забезпечило найвищий рівень середньої врожайності по фонах: без добрив - 2,70-2,72 т/га, органічному - 2,87-3,23 т/га, органо-мінеральному - 3,14-3,83 т/га. В найбільш несприятливих умовах 2019 з. незалежно від фону живлення більш стійкими до посухи були сорти Царевич і Отаман. При цьому середня врожайність сортів на неудобреному фоні составила $0,81 \mathrm{~T} /$ га, а на органічному та органо-мінеральному було одержано істотні надбавки зерна - відповідно 0,39 т/га та 0,48 т/га.

Висновки. У середньому за 2016-2020 рр. найкраще реагували на внесення добрив сорти Царевич та Гайдук, надбавки зерна яких до контролю були стабільно високими відповідно 0,44 і 0,47 т/га на фоні післядії гною та 0,84 і 0,79 т/га - за додаткового внесення $\mathrm{N}_{30} \mathrm{P}_{30} \mathrm{~K}_{30}$. За роки досліджень у середньому по сортах органічний та органо-мінеральний фони живлення забезпечили істотний приріст урожайності - відповідно на 0,38 та 0,69 т/га, при врожайності на контролі 2,21 т/га.

Виявлена відмінність якості зерна залежно від сорту та фону живлення. Найвищу білковість зерна забезпечили найменш урожайні сорти Корвет і Малахіт із показниками відповідно 24,09 і 23,35 \% на контролі та 24,63 і 23,39 \% - на органо-мінеральному фоні удобрення. Встановлена можливість одночасного зростання врожайності та вмісту білка в зерні сорту Гайдук. Найбільш істотний валовий збір білка одержано на органомінеральному фоні у сортів Гайдук, Оплот і Царевич $(0,682-0,689$ т/га) 3 приростом 16,817,8 \% до стандартного сорту Девіз. Підвищення валового збору білка з гектара у більшості сортів залежало від рівня їх врожайності, ніж від вмісту білка в зерні.

Ключові слова: горох, сорт, фон живлення, врожайність, якість зерна, збір білка

\section{ПРОДУКТИВНОСТЬ УСАТЫХ СОРТОВ ГОРОХА В ЗАВИСИМОСТИ ОТ ФОНА ПИТАНИЯ В УСЛОВИЯХ ВОСТОЧНОЙ ЛЕСОСТЕПИ УКРАИНЫ}

Попов С.И., Глубокий А.Н.

Институт растениеводства им. В.Я. Юрьева НААН, Украина

Цель исследований - установить влияние системы основного удобрения в севообороте на урожайность и качество зерна усатых сортов гороха в условиях восточной Лесостепи Украины.

Материалы и методы. Полевые исследования проводили в период 2016-2020 гг. в стационарном севообороте Института растениеводства им. В.Я. Юрьева НААН Украины. Почва - чернозем мощный слабовыщелоченный. Объектом изучения были семь районированных сортов - Девиз, Царевич, Отаман, Оплот, Корвет, Гайдук и Малахит. Схема опыта включала три фона: севооборотный (без удобрений); 2 - органический (последействие навоза); 3 - органо-минеральный (последействие навоза $+\mathrm{N}_{30} \mathrm{P}_{30} \mathrm{~K}_{30}$ в основное внесение). Технология выращивания - общепринятая для зоны. Статистическую обработку экспериментальных результатов проводили методом дисперсионного анализа.

Обсуждение результатов. В нестабильных погодных условиях 2016-2020 гг. на неудобренном фоне самый высокий уровень урожайности обеспечили сорта Царевич 
(2,33 т/га), Гайдук (2,28 т/га) и Оплот (2,27 т/га) с превышением стандартного сорта Девиз на 0,19-0,25 т/га. В зависимости от года исследований максимальная урожайность сортов изменялась в пределах 3,04-3,21 т/га, минимальная - 0,77-0,88 т/га, а размах вариации составил 2,27-2,38 т/га.

На органическом фоне продуктивность этих сортов (2,75-2,77 т/га) превышала стандарт в среднем на 0,43-0,45 т/га, а по сравнению с неудобренным фоном прибавка урожая зерна составила 0,44-0,45 т/га или 18,9-21,5 \%. Наиболее высокую урожайность $(3,04-3,07$ та т/га) и прибавку зерна $(0,77-0,84$ т/га) обеспечили сорта Царевич, Гайдук и Оплот на органо-минеральном фоне, что свидетельствует о хорошей их реакции на удобрения и возможности выращивания по интенсивной технологии. В годы исследований максимальная урожайность этих сортов составила 4,16-4,39 т/га, минимальная - 1,27-1,51 т/га, а размах ее варьирования был наивысший - от 2,79 до 2,89 т/га. Наименьшую прибавку зерна на органо-минеральном фоне удобрения получен у сортов Малахит и Корвет - соответственно 0,47 та 0,56 т/га. При этом размах вариации урожайности по годам был наименьшим - 2,43-2,44 т/га.

Наиболее благоприятные погодные условия для гороха сложились в 2016, 2017 та 2020 гг., что обеспечило соответственно самый высокий уровень средней урожайности сортов по фонах: без удобрения - 2,70-2,72 т/га, органический - 2,87-3,23 т/га, органо-минеральный - 3,143,83 т/га. В наиболее неблагоприятных условиях 2019 г. независимо от фона питания более устойчивыми к засухе были сорта Царевич и Отаман. При этом средняя урожайность сортов на неудобренном фоне составила 0,81 т/га, а органический и органоминеральный фоны питания обеспечили существенную прибавку зерна - соответственно 0,39 т/га та 0,48 т/га.

Выводы. В среднем за 2016-2020 гг. наиболее отзывчивыми на внесение удобрений были сорта Царевич та Гайдук, прибавки урожая у которых были стабильно высокими соответственно 0,44 и 0,47 т/га на органическом фоне (последействие навоза) и 0,84 і 0,79 т/га - при основном внесении $\mathrm{N}_{30} \mathrm{P}_{30} \mathrm{~K}_{30}$ на органическом фоне. В среднем по сортам органический и органо-минеральный фоны удобрений обеспечили повышение их продуктивности соответственно 0,38 та 0,69 т/га, при урожайности на контроле 2,21 т/га. Выявлена зависимость качества зерна гороха от сорта и фона питания. Самая высокая белковость зерна была в менее урожайных сортов Корвет и Малахит с показателями соответственно на контроле 24,09 и 23,35 \%, а на органо-минеральном фоне - 24,63\% и $23,39 \%$.

Установлена возможность одновременного повышения урожайности и содержания белка в зерне сорта Гайдук. Наиболее существенный валовой сбор белка получено на органоминеральном фоне питания у сортов Гайдук, Оплот и Царевич $(0,682-0,689$ т/га) с увеличением показателей на 16,8-17,8 \% по сравнению со стандартным сортом Девиз. Повышение валового сбора белка с гектара у большинства сортов зависело от уровня их урожайности, чем от содержания белка в зерне.

Ключевые слова: горох, фон питания, урожайность, качество зерна, сбор белка

\section{PRODUCTIVITY OF MUSTACHIOED PEA VARIETIES DEPENDING ON THE NUTRITION BACKGROUND UNDER THE CONDITIONS OF THE EASTERN FOREST- STEPPE OF UKRAINE}

Popov S.I., Hlubokyi O.M.

Plant Production Institute nd. a. V.Ya. Yuriev of NAAS, Ukraine

The purpose of the research was to find out the effect of the main fertilization system in the crop rotation scheme on the yield and quality of seeds of moustachioed pea varieties in the Eastern Forest-Steppe of Ukraine. 
Materials and methods. Field studies were carried out in the period 2016-2020 in the stationary crop rotation scheme of V.Y.Yuriev Plant Production Institute of NAAS of Ukraine. The soil is powerful, poorly leached chernozem. The object of study were seven zoned varieties - Deviz, Tsarevych, Otaman, Oplot, Korvet, Haiduk and Malakhit. The experiment scheme included three backgrounds: 1 - crop rotation (without fertilizers); 2 - organic (manure aftereffect); 3 - organomineral (aftereffect of manure $+\mathrm{N}_{30} \mathrm{P}_{30} \mathrm{~K}_{30}$ in the main application). The cultivation technology is generally accepted for the zone. The experimental results were statistically processed by the method of analysis of variance.

Results and discussion. In unstable weather conditions 2016-2020 on the unfertilized background, the highest yield level was provided by the varieties Tsarevych $(2.33 \mathrm{t} / \mathrm{ha})$, Haiduk $(2.28 \mathrm{t} / \mathrm{ha})$ and Oplot $(2.27 \mathrm{t} / \mathrm{ha})$ with an excess of the standard variety Deviz by $0.19-0,25 \mathrm{t} / \mathrm{ha}$. Depending on the year of research, the maximum yield of these varieties varied within 3.04-3.21 t/ha, the minimum yield was $0.77-0.88 \mathrm{t} / \mathrm{ha}$, and the range of variation was $2.27-2.38 \mathrm{t} / \mathrm{ha}$. The productivity of the above mentioned varieties $(2.75-2.77 \mathrm{t} / \mathrm{ha})$ exceeded the standard by an average of $0.43-0.45 \mathrm{t} / \mathrm{ha}$ on the organic background, and compared with the unfertilized background, the increase in grain yield was $0.44-0.45 \mathrm{t} /$ ha or $18.9-21.5 \%$.

The highest yield (3.04-3.07 t/ha) and an increase in grain $(0.77-0.84 \mathrm{t} / \mathrm{ha})$ were provided by the varieties Tsarevych, Haiduk and Oplot on the organo-mineral background. This testifies to their good response to fertilizers and the possibility of cultivation using intensive technology. During the years of research, the maximum yield of these varieties was 4.16-4.39 $\mathrm{t} / \mathrm{ha}$, the minimum $1.27-1.51 \mathrm{t} / \mathrm{ha}$, and the highest range of its variation was from $2.79 \mathrm{t} / \mathrm{ha}$ to $2.89 \mathrm{t} / \mathrm{ha}$. The smallest increase in grain on the organo-mineral background of fertilization was obtained in the varieties Malakhit and Korvet $-0.47 \mathrm{t} / \mathrm{ha}$ and $0.56 \mathrm{t} / \mathrm{ha}$ respectively. At the same time, the range of yield variation over the years was the smallest $-2.43-2.44 \mathrm{t} / \mathrm{ha}$.

The most favourable weather conditions for peas were in 2016, 2017 and 2020. Accordingly, this provided the highest level of average yield of varieties in terms of backgrounds: without fertilization $-2.70-2.72 \mathrm{t} / \mathrm{ha}$, organic $-2.87-3.23 \mathrm{t} / \mathrm{ha}$, organo-mineral $-3.14-3.83 \mathrm{t} / \mathrm{ha}$. In the most unfavourable weather conditions of 2019, regardless of the nutritional background, the Tsarevych and Otaman varieties were more resistant to drought. The average yield of these varieties on the unfertilized background was $0.81 \mathrm{t} / \mathrm{ha}$. At the same time, organic and organomineral nutritional backgrounds provided a significant increase in the grain - respectively 0.39 $\mathrm{t} / \mathrm{ha}$ and $0.48 \mathrm{t} / \mathrm{ha}$.

Conclusions. On average for 2016-2020, the Tsarevych and Haiduk varieties were the most responsive to fertilization. The increase in grain of these varieties were consistently high -0.44 and $0.47 \mathrm{t} / \mathrm{ha}$ on the organic background (aftereffect of manure) and 0.84 and $0.79 \mathrm{t} / \mathrm{ha}$ with the main application of $\mathrm{N}_{30} \mathrm{P}_{30} \mathrm{~K}_{30}$ on the organic background respectively. On average, organic and organo-mineral fertilizer backgrounds for Tsarevych and Haiduk varieties ensured an increase in their productivity $0.38 \mathrm{t} / \mathrm{ha}$ and $0.69 \mathrm{t} / \mathrm{ha}$ respectively, with a yield under control (without fertilizers) of $2.21 \mathrm{t} / \mathrm{ha}$.

The dependence of the quality of pea grain on the variety and nutrition background was revealed. The highest protein content of grain was obtained in less productive varieties of Korvet and Malakhit with indicators, in the control of 24.09 and $23.35 \%$, and on the organic-mineral background $-24.63 \%$ and $23.39 \%$ respectively.

The possibility of the simultaneous increase in yield and protein content in the grain of the Haiduk variety has been established. The most significant gross protein harvest was obtained on the organic-mineral nutritional background in the Haiduk, Oplot and Tsarevych varieties $(0.682-$ $0.689 \mathrm{t} / \mathrm{ha}$ ) with an increase of $16.8-17.8 \%$ in comparison with the standard variety Devyz. The increase in the gross yield of protein per hectare, in most varieties, depended on the level of their yield rather than on the protein content in the grain.

Key words: peas, variety, nutrition background, productivity, grain quality, protein harvest. 